\title{
GOSTOVANJE PROF. DR. MICHAELA WOODSA NA ODDELKU ZA GEOGRAFIJO FILOZOFSKE FAKULTETE UNIVERZE V LJUBLJANI
}

Prof. dr. Michael Woods spada med vodilne evropske strokovnjake za podeželje. Strokovni in širši javnosti so poznani njegovi cenjeni učbeniki (Rural geography - več izdaj), teoretski prispevki (Rural, 2011; več člankov v Progress in human geography, Sociologia ruralis ipd.), pa tudi urednikovanje Journal of rural studies. Dr. Woods je profesor za družbeno geografijo in direktor Inštituta za geografijo na Univerzi v Aberystwythu (Wales, Združeno kraljestvo) in je z Oddelkom za geografijo FF UL že sodeloval v projektu DERREG (Developing Europe's rural regions in the era of globalization - 7. okvirni program EU; več na: www.derreg.eu).

Od 22. do 26. aprila 2013 je predaval več kot stotim slušateljem. Prvo predavanje (Relational theory and researching place) je bilo namenjeno doktorskim študentom, prišli so tudi univerzitetni profesorji iz Ljubljane, Maribora in Sarajeva in iz različnih znanstvenih disciplin (Biotehniška fakulteta, Fakulteta za gradbeništvo in geodezijo, Fakulteta za arhitekturo, ZRC SAZU, Oddelek za geografijo Filozofske fakultete Univerze v Ljubljani in Oddelek za geografijo Filozofske fakultete Univerze v Mariboru, Univerza na Primorskem). Predavanje je posredovalo izjemno bogato teoretsko sporočilo t. i. relational theo$r y$ (se osredotoča na vzpostavljanje in delovanje interakcij v družbi in prostoru), ki izhaja iz pomembnih razprav več avtorjev (Amin, Massey, Murdoch). Le-ti zagovarjajo tezo, da je prostor zamotano omrežje družbenih, gospodarskih in kulturnih odnosov. Predavanje se je osredotočilo na globalizacijo in njene učinke na lokalna gospodarstva in kulture. Dojemanje podeželskega prostora je trizložno (Halfacree), na čemer temeljijo tudi predlogi metod, ki so uporabne pri tovrstnem raziskovanju.

Javno predavanje (The global countryside? Rural agency and transformation in globalization) je udeležencem - zelo raznovrstni skupini ljudi iz akademskih krogov, strokovnih služb in prakse iz različnih generacij - predstavilo več obrazov globalizacije. Poleg (običajno poznanega) negativnega se je dr. Woods osredotočil tudi na prepoznavanje pozitivnih izkušenj, ki jih prinašajo procesi globalizacije. V izhodišču je bila predstavljena ideja globaliziranega podeželja, ki ni homogeno, ampak postaja vse bolj zapleten prostor, kjer lahko podeželske skupnosti v podobnih situacijah zelo različno odreagirajo na raznovrstne pritiske. Navedeno je bilo predstavljeno $v$ treh poglobljenih študijah primera: konflikti zaradi mednarodnih selitev (vzrok selitev: privlačnost pokrajine) na Novi Zelandiji, pobude avstralskih kmetov za razvoj mednarodnih poslovnih povezav ter politična mobilizacija proti globalizaciji v Franciji.

Tretje predavanje (Globalization and rural development) je bilo namenjeno magistrskim študentom in je ponovno privabilo raznovrstne ciljne skupine. Učinke globalizacije je tokrat dr. Woods obravnaval z vidika glokalizacije. Tako je izpostavil in primerjal pristope k razvoju podeželja na Irskem (državni intervencionizem), v Avstraliji (neoliberalni pristop) in na Kitajskem (dvotirni pristop). 
Nadaljnje delo je bilo usmerjeno v geografsko aplikacijo, h konkretnim usmeritvam glede razvoja podeželja. Skupaj s profesorjem Woodsom smo izvedli terensko delo v občini Izola, katere podeželje je zaznamovano z neuravnoteženo rabo, nesoglasji med varovanjem kulturne pokrajine in pričakovanji lokalnega in doseljenega prebivalstva itd. $\mathrm{Na}$ tem zelo kompleksnem podeželskem območju smo prepoznavali odločilne akterje, izdelovali razvojne scenarije in predvidevali učinke izbranih razvojnih ukrepov.

Drugi terenski sklop je bil vezan na delovanje lokalne akcijske skupine (LAS) v okviru programa LEADER. Na območju občin Ilirska Bistrica, Pivka in Postojna deluje LAS Zeleni kras. Na terenu smo analizirali učinke nekaterih že izvedenih projektov (grad Prem, izdelava sirov iz ovčjega mleka, turistična ponudba v Brkinih ipd.) in pripravili zasnovo tematik, ki bi jih vključili t. i. socialnokulturni atlas. Predavanja prof. dr. Michaela Woodsa so pomembno obogatila naš študijski program in oživila ter spodbudila raznovrstne razprave o razvoju podeželja.

Gostovanje je finančno podprla Univerza v Ljubljani, ki je bila izbrana na osnovi javnega razpisa za sofinanciranje gostujočih visokošolskih učiteljev v pedagoški proces v letih 2011-2013. Gostovanja delno financira Evropska unija iz Evropskega socialnega sklada in se izvajajo v okviru Operativnega programa razvoja človeških virov 20072013 (razvojna prioriteta 3: Razvoj človeških virov in vseživljenjskega učenja; prednostna usmeritev 3.3 Kakovost, konkurenčnost in odzivnost visokega šolstva).

Irma Potočnik Slavič

\section{ERRATUM}

V 39. številki revije DELA je napaka v številki DOI pri članku M. Žebre, U. Stepišnika in B. Kodelje z naslovom Sledovi pleistocenske poledenitve na Trnovskem gozdu (str. 157).

Pravilna številka DOI je: DOI: 10.4312/dela.39.9.157-170

In 39th issue of the magazine DELA, there is an error in the DOI number of the article Traces of Pleistocene glaciation on Trnovski gozd (authors M. Žebre, U. Stepišnik, B. Kodelja) on page 157. The correct DOI number is: DOI: 10.4312/dela.39.9.157-170 